\title{
Estimates of Consumer Price Response in Pakistan using Market Prices as Data
}

\author{
HAROLD ALDERMAN*
}

The main emphasis of the paper is to illustrate a methodology that can be readily applied to future data analysis. The results presented here indicate that plausible and detailed estimates of consumer response to price changes can be obtained using household expenditure surveys and published price series in a manner that does not require the assumptions of additive preferences. It is noted that a fixed-effects. approach which sweeps out spatial long-run price differences can be employed as a replicated time series even over a limited period of four quarters.

The most complete estimates of consumer responsiveness to changes in relative prices in Pakistan have been generated by variations of the Linear Expenditure System (LES) or Extended Linear Expenditure System (ELES) [Ahmad et al. (1986); Ali (1985); Mukhtar (1985)] . While these studies are technically competent and innovative, they derive their estimates of price elasticities without the use of price data. This is possible with the LES or ELES because all parameters can be identified with marginal budget shares and an estimate of "committed expenditure" for a single commodity. This latter parameter can be identified from savings behaviour or inferred from other household characteristics. Not only is there some question as to the reliability of this identification, the underlying utility function assumes additive preferences. This implies that the marginal utility of one good is independent of the quantity of other goods consumed. This is not a plausible assumption for food commodities and has been found invalid for even broad commodity groups [Deaton (1975); Blundell and Ray (1984)].

In the present study, estimates of income and price elasticities are obtained using the Almost Ideal Demand System (AIDS) (Deaton and Muellbauer 1980), which is more flexible than the LES or ELES. The data come from the 1979 consumer expenditure survey as well as a similar urban survey conducted in 1982 using a virtually identical questionnaire. ${ }^{1}$ These data sets, however, do not include prices

*Dr Harold Alderman, International Food Policy Research Institute, Washington, D.C., wishes to thank Zakir Hussain, Larry Morgan, and an anonymous reviewer for helpful comments.

${ }^{1}$ Data on tape was provided through the kind assistance of the Federal Bureau of Statistics. 
in all cases. This is not necessarily a drawback, however, as prices derived from in all cases. This is not necessarily a do biased price parameters depending on whether quantities, prices, and expenditures are recorded independently or derived by multiplication or division of other data (Deaton 1986). Here, the prices come from the ponthly Statistical Bulletin. Published by the Federal Bureau of various issues of the Monthly Statistical Bulletin. Published by the employed in the estimation, then, are practical steps for linking the data sources and in aggregation over commodities. The solutions offered are pragmatic and, therefore, less neat than algebraic derivations. Consequently, they are discussed in some detail below.

\section{THE MODEL}

The Almost Ideal Demand System is derived from a generalized cost function.

$$
\log C(u, p)=a(p)+u \log [b(p)] \ldots \quad \ldots \quad \ldots
$$

where:

$$
a(p)=a_{o}+\sum_{k} a_{k} \log P_{k}+1 / 2 \sum_{k} \sum_{j} \gamma_{k j} \log P_{k} \log P_{j} \quad \cdots
$$

and

$$
\log [b(p)]=\log \beta_{o}+\Sigma_{k} \log P_{k} \quad \ldots \quad \ldots \ldots
$$

The terms $u$ and $p$ represent utility and prices, respectively. The $\alpha, \beta$, and $\gamma$ terms are parameters of the model. Using duality theory, one derives the estimating equations in terms of budget shares.

$$
w_{i}=\alpha_{i}+\sum_{j} \gamma_{i j} \log P_{j}+\beta_{i} \log \left(\frac{X}{P^{*}}\right) \quad \ldots \quad \ldots \ldots
$$

where $w_{i}$ is the budget share of the $i$ th good, $P_{j}$ is the price of the $j$ th good, and $X$ is total expenditures. The $\alpha, \beta$, and $\gamma$ terms are parameters to be estimated, while $P^{*}$ is an exact price index based on $c(u, p)$. In the nonlinear version of the system, the weights in this index are internally derived from the parameters of the system. In the linearized form, used here, the index is:

$$
\log P^{*}=\sum_{j} w_{j} \log P_{j}
$$

Since budget shares add up to one, $\sum_{i} a_{i}=1, \underset{i}{\sum} \beta_{i}=0$, and $\underset{i}{\sum} \gamma_{i j}=0$. One can, therefore, drop one equation in the system estimation. Homogeneity can be imposed by restricting $\sum_{j} \gamma_{i j}=0$. This restriction is tested below. Furthermore, Slutsky sym metry can be imposed if $\gamma_{i j}=\gamma_{j i}$.

Although the underlying Engel curve - the Leser-Working function form is a more plausible form than the linear curves underlying the LES, further flexibility can be added by including a term for the square of the logarithm of income. As household data are available, the model also includes the logarithm of household size and the proportion of children five years of age or under to allow for scale effects. Again, adding up of budget shares implies that the coefficients of these terms sum to zero across equations.

\section{DATA}

The 1979 Household Income and Expenditure Survey contains observations on a total of nearly 20,000 households, collected over four quarterly rounds. The estimations are based on such household observations rather than cell means. The monthly price data represent information on prices of hundreds of commodities from retail markets in 12 urban centres. There are, then, two distinct difficulties in linking these two data sources. First, there is not an exact correspondence between the commodity groupings reported in the household survey and the price series. Second, the retail prices are for markets that do not necessarily correspond to the markets in which the households make their purchases.

This latter problem is actually the easier one to tackle. For example, in the rural estimation, the 39 district codes were linked to the closest urban market. If farmgate and village prices differ from urban prices by a constant proportion across the sample, no further adjustment would be necessary in order to estimate the correct slope parameters. It is not necessary, however, to rely on this assumption. The approach used below nets out the means of each variable for the district from each household observation. This fixed-effects approach, which is equivalent to including a dummy variable for each district, controls for unobserved district effects (Hausman 1978). Denoting any general model as:

$$
W_{h t}=X_{h t} \beta+\lambda_{d}+u_{h t}
$$

where the $h, t$, and $d$ subscripts refer to households, time periods, and districts, respectively. Both $\lambda_{d}$ and $u_{h}$ are unobserved components of the error term. If the variable $\lambda_{d}$, which can be a linear combination of various price markups or discounts as well as other district-specific effects, is correlated with the $X$ 's, exclusion of the term can lead to biased estimators. The netting out of village means transforms the model to

$$
\left(W_{h t}-\bar{W}_{d}\right)=\left(X_{h t}-\bar{X}_{d}\right)+\left(\lambda_{d}-\bar{\lambda}_{d}\right)+\left(u_{h t}-\bar{u}_{d}\right)
$$


If $\lambda_{d}$ is fixed, then $\left(\lambda_{d}-\bar{\lambda}_{d}\right)$ equals zero and this effect drops out. Spatial or regional differences in prices, then, do not affect the fixed-effect model. The price parameters estimated in this manner can be interpreted as a short-run response, an interpretation that is not generally warranted with estimates from cross-sectional survey data.

The fixed-effects form discussed above is strictly appropriate only when regional-specific effects enter the model linearly. This implies that the effects of ethnicity or habits influence the intercept but not the slope. It also implies that price markups or discounts are proportional to unit prices, given the logarithmic form in which prices are entered. This is a common means of modelling marketing margins, and is supported by empirical evidence although clearly this is only an approximation of more complex models of price formations (Timmer 1974). Thus the approach used mitigates, but does not necessarily eliminate, the handicap of the absence of village-specific prices.

The price movement that allows for parameter estimation is the movement over four quarters. Estimates using such a short-term series are possible because there are thousands of observations in each round. The time series, then, is replicated. In order to mitigate the possible confusion of seasonal patterns, dummy variables for each round are included in the estimates. ${ }^{2}$ Note that the district averages in Equation 4 are not taken for each round. To do so would be equivalent to having four separate dummy variables for each district. Such an approach would preclude estimation of price response, though income parameters would still be estimable.

Eight commodity groups are included in the study: wheat products (including bread and nan), rice, pulses, dairy products, meat (including eggs, fish, and poultry), other foods, fuel, and other nonfoods. In the urban sample, which has. more price variation, an additional group, fats and oils, is included. This group is aggregated with other foods in the rural sample. For some of these groupings, such as pulses, published prices can be found that correspond to all the elements in the group. In such cases, it is straightforward to construct a commodity price index with the weights being the average share of expenditure in the group devoted to the individual good. For wheat products, however, the survey category corresponds to an aggregate of wheat as well as rationed and nonrationed flour for which there are five prices in the published price series. If these prices moved in parallel, of course, any one of the prices would be an adequate representative for the category. This is not the case, however, and some prior information is necessary to construct the price

${ }^{2}$ To the degree that seasonality in consumption is due to seasonal patterns of employment or prices, there is no need for such dummy variables; such seasonal patterns allow for the identification of demand patterns. However, other seasonal effects, such as festivals or climate-induced demand for fuel or clothing, should be accommodated. index. A survey conducted in 1976 reports the share of wheat, market flour, and ration flour in the total wheat products budget, Government of Pakistan (1978). [See also Cornelisse and Naqvi (1984)], for similar data from 1982. Using that data, a wheat product price index can be constructed. For rural areas, the weights for grain wheat, market flour, and ration flour were $0.76,0.21$, and 0.03 , respectively. Similar weights for urban areas were $0.21,0.39$, and 0.50 , respectively.

Underlying this index are two assumptions. The first is that movement in nan prices correlates sufficiently strongly with movement in the included flour and wheat prices that its exclusion from the index will not affect results. ${ }^{3}$ Second, and more worrisome, is the assumption that the quota on ration flour is not binding. For rural areas, ration flour consumption is sufficiently small that it is not a concern.

In urban areas, ration flour quotas are more likely to have influenced purchases. In 1976, roughly half the urban population consumed their full quotas. Using this data, Ahmad et al. (1986a) have estimated a wheat flour price elasticity that models the kink in the budget constraint implied by the quota system. The information for a similar approach with this data, however, do not exist. Furthermore, the assumption that ration and market flour differ only in price and not quality which is necessary for these approach may not be valid for all years. In addition, this approach is designed for the specific question of the demand for flour and is not readily adaptable for the heterogenous grouping of wheat and flour. The unavailability of information on ration flour consumption, then, is a limitation of the urban data set which must be considered in interpreting the results below.

\section{RURAL RESULTS}

The price and expenditure elasticities derived from the estimates for the rural regressions are indicated in Tables 1 and 2. The data in the former table are from the fixed-effects model and are the parameters that should be applied to projections or policy modelling. ${ }^{4}$ The results in Table 2 are for the version of the system that does not correct for district means and are presented only for comparison. They are conceptually less plausible than the results in Table 2, although the approach is commonly employed with cross-sectional demand. Note that for all but one commodity, the $F$-statistic testing the restriction of homogeneity on a single-equation basis is lower with the fixed-effects model (see Table 3 ) than with the corresponding test in the pooled cross-sectional model. This restriction has been rejected with time-series and pooled cross-section and time-series data, but has not been widely tested with

${ }^{3}$ Regional differences in purchase patterns for bread are controlled for in the fixed effects approach.

${ }^{4}$ Coefficients of the Variables in the estimating equations and $t$-statistics are in Appendix Table 1. 
Price and Expenditure Elasticities from Rural Fixed-effects Model (calculated at sample means)

Compensated Price Elasticity with Respect to Price of

Commodity

Expendi-

Budget ture Wheat Rice Pulses Dairy Meat Other Fuel Nonfood

Share Elasticity Food

\begin{tabular}{|c|c|c|c|c|c|c|c|c|c|c|}
\hline Wheat & 0.134 & 0.36 & -0.91 & 0.32 & -0.04 & -0.13 & -0.05 & 0.02 & -0.02 & -0.20 \\
\hline Rice & 0.025 & 0.96 & 1.73 & -1.91 & -0.09 & 0.65 & 0.66 & -0.55 & -1.28 & -0.20 \\
\hline Pulses & 0.024 & 0.55 & -0.23 & -0.10 & -0.52 & 0.55 & -0.57 & -0.18 & 0.20 & -0.15 \\
\hline Dairy Products & 0.146 & 1.37 & -0.12 & 0.11 & 0.09 & -1.06 & -0.16 & 0.13 & 0.09 & -0.08 \\
\hline $\begin{array}{l}\text { Meat } \\
\text { (incl. Poultry) }\end{array}$ & 0.039 & 1.51 & -0.16 & 0.42 & -0.35 & -0.58 & -0.29 & -0.35 & -0.46 & 0.76 \\
\hline Other Food & 0.185 & 0.80 & 0.02 & -0.07 & 0.02 & 0.11 & -0.07 & -1.04 & -0.03 & 0.11 \\
\hline Fuel & 0.064 & 0.62 & -0.04 & -0.50 & 0.08 & 0.18 & -0.28 & -0.09 & -0.71 & 0.36 \\
\hline Nonfood & 0.383 & 1.22 & -0.07 & -0.01 & -0.01 & -0.03 & 0.08 & 0.06 & 0.06 & -1.07 \\
\hline
\end{tabular}

Table 2

Price and Expenditure Elasticities from Rural Pooled Cross-sectional Model (calculated at sample means)

\begin{tabular}{|c|c|c|c|c|c|c|c|c|c|c|}
\hline \multirow[b]{2}{*}{ Commodity } & \multirow[b]{2}{*}{$\begin{array}{c}\text { Budget } \\
\text { Share }\end{array}$} & \multirow[b]{2}{*}{$\begin{array}{l}\text { Expendi- } \\
\text { ture } \\
\text { Elasticity }\end{array}$} & \multicolumn{8}{|c|}{ Compensated Price Elasticity with Respect to Price of } \\
\hline & & & Wheat & Rice & Pulses & Dairy & Meat & $\begin{array}{l}\text { Other } \\
\text { Food }\end{array}$ & Fuel & Nonfood \\
\hline Wheat & 0.134 & 0.33 & -1.25 & 0.20 & -0.03 & -0.79 & -0.02 & 0.39 & 0.00 & 0.49 \\
\hline Rice & 0.025 & 1.01 & 1.05 & -0.25 & -0.33 & -0.94 & 2.22 & 1.62 & -0.81 & -3.25 \\
\hline Pulses & 0.024 & 0.57 & -0.14 & -0.34 & -0.39 & 0.31 & -0.47 & -0.21 & -0.27 & 0.52 \\
\hline Dairy Products & 0.146 & 1.32 & -0.72 & -0.16 & 0.05 & -2.84 & 0.55 & 1.24 & 0.17 & 0.71 \\
\hline Meat & & & & & & & & & & \\
\hline (incl. Poultry) & 0.039 & 1.50 & -0.05 & 1.42 & -0.29 & 2.06 & -0.07 & -2.32 & -1.04 & -0.71 \\
\hline Other Food & 0.185 & 0.56 & 0.29 & 0.22 & -0.03 & 0.98 & -0.49 & -0.74 & 0.34 & -1.57 \\
\hline Fuel & 0.064 & 0.64 & -0.01 & -0.32 & -0.10 & -0.38 & -0.64 & 0.88 & -0.54 & -0.76 \\
\hline Nonfood & 0.383 & 1.22 & 0.17 & -0.23 & 0.03 & 0.27 & -0.07 & -0.76 & -0.13 & -0.28 \\
\hline
\end{tabular}


household-level observations (Ray 1982). In the rural sample, the distinction between the fixed-effects and the standard approach is most dramatic in the case of wheat where homogeneity is decisively rejected in the standard pooled cross-section model, although the fixed-effects model fails to reject at $p<0.10$. These tests of homogeneity are presented to indicate differences between the two approaches to modelling. The results reported in Tables 1 and 2 as well as subsequently are from systems which imposed both homogeneity and symmetry.

As expected, the expenditure elasticities at the mean of the sample differ little between the two models. The relative magnitudes of these elasticities are also reasonable. Meat, nonfood, and dairy products are luxury goods, while wheat has the lowest expenditure elasticity.

Table 3

Tests of Homogeneity in Füxed-effects and Pooled Cross-sectional Models

\begin{tabular}{|c|c|c|c|c|}
\hline \multirow{3}{*}{ Commodity } & \multicolumn{4}{|c|}{$F$-test Statistic } \\
\hline & \multicolumn{2}{|c|}{ Rural } & \multicolumn{2}{|c|}{ Urban } \\
\hline & $\begin{array}{l}\text { Fixed- } \\
\text { effects }\end{array}$ & $\begin{array}{l}\text { Cross- } \\
\text { sectional }\end{array}$ & $\begin{array}{l}\text { Fixed- } \\
\text { effects }\end{array}$ & $\begin{array}{c}\text { Cross- } \\
\text { sectional }\end{array}$ \\
\hline Wheat & 0.8 & 485.0 & 41.2 & 0.7 \\
\hline Rice & 8.8 & 347.8 & 24.6 & 51.9 \\
\hline Pulse & 5.5 & 71.6 & 0.0 & 0.6 \\
\hline Dairy & 57.0 & 13.0 & 0.6 & 18.1 \\
\hline Meat & 0.0 & 0.1 & 0.8 & 0.2 \\
\hline Oil & - & - & 3.0 & 0.5 \\
\hline Other Food & 3.7 & 108.4 & 53.1 & 194.8 \\
\hline Fuel & 6.0 & 9.4 & 8.5 & 14.6 \\
\hline
\end{tabular}

The price elasticities differ between the two models in a number of cases. Only about half the price parameters in the fixed-effects model differ from zero at conventional levels of significance, while most do in the pooled cross-sectional model. ${ }^{5}$ This reflects the fact that the fixed-effect transformation reduces the price variance in the sample. In both sets of estimates, there are a few relationships that are surprising; in the fixed-effects, the magnitude of the rice own-price elasticity is higher than expected and the apparent complementarity of dairy and meat is unexpected, while in the pooled cross-sectional model, the nonfood price elasticities, as well as some of the other cross-price elasticities, are higher in absolute value than might be expected for a short-run change in price.

\section{URBAN RESULTS}

Inasmuch as data were available for 1982 for urban areas, the estimates for that sector use more information and have more movement in relative prices. The survey instruments were virtually identical in both years which facilitates linking of data. A major difference in the approach is that the 1982 survey was not conducted in rounds. In the smaller cities, the survey was completed within a few weeks of initiation (February 1982) and, therefore, there is no difficulty in using the retail price series from March 1982 to derive the prices for the estimation. For larger cities, however, the data collection continued throughout the year with no indication of interview date recorded in the data. As the duration of the data collection interval is known, it is possible to approximate the mid-point of each urban centre in order to choose the most appropriate monthly prices. However, as this duration is greater the larger the population of the city, the average absolute deviation between the date of the reported price and the unknown date of household recall increases as one goes from cities like Bannu and Chiniot to Karachi and Lahore. While undoubtedly some error is introduced into the data by the lack of information on interview dates, the linking of the two surveys provides greater movement in relative prices and improved accuracy in estimates of price response.

The urban fixed-effects model exhibits less pronounced money illusion than does its counterpart in only about half the commodity equations. Note that homogeneity is decidedly rejected in a number of cases. This may reflect the problems in linking the data referred to above.

Expenditure elasticities are quite similar between urban and rural areas, as well as between approaches to modelling the data (Tables 4 and 5). This is particularly noteworthy because average expenditure levels differ between rural and urban areas.

${ }^{5}$ The compensated own-price elasticity in budget-share equations of the form indicated in Equation 2 is $\left(\gamma_{i i} / \bar{W}_{i}\right)-1$. Hence, when $\gamma_{i i}$ is not statistically different from zero, the own-price elasticity is not different from -1 . 
Table 4

Price and Expenditure Elasticities from Urban Fixed-effects Model

Compensated Price Elasticity with Respect to Price of

\begin{tabular}{|c|c|c|c|c|c|c|c|c|c|c|c|}
\hline Commodity & $\begin{array}{l}\text { Budget } \\
\text { Share }\end{array}$ & $\begin{array}{l}\text { Expendi- } \\
\text { ture } \\
\text { Elasticity }\end{array}$ & Wheat & Rice & Pulses & Dairy & Meat & Oils & $\begin{array}{l}\text { Other } \\
\text { Food }\end{array}$ & Fuel & Nonfood \\
\hline Wheat & 0.072 & 0.35 & -0.31 & 0.11 & 0.19 & -0.37 & -0.51 & -0.06 & -0.15 & 0.45 & -0.34 \\
\hline Rice & 0.019 & 0.83 & 0.42 & -0.93 & -0.02 & 0.42 & 0.18 & -0.03 & 0.32 & -0.60 & -0.75 \\
\hline Pulses & 0.020 & 0.42 & 0.69 & -0.02 & -0.33 & 0.24 & -0.17 & -0.05 & -0.04 & -0.43 & -0.87 \\
\hline Dairy & 0.086 & 1.05 & -0.42 & 0.09 & 0.06 & -0.76 & 0.00 & -0.01 & 0.02 & -0.02 & 0.04 \\
\hline Meat & 0.054 & 1.30 & -0.50 & 0.06 & -0.06 & 0.00 & -1.01 & -0.26 & 0.14 & 0.14 & 0.49 \\
\hline Oils & 0.044 & 0.51 & -0.08 & -0.01 & -0.02 & -0.02 & -0.32 & -0.08 & -0.07 & -0.07 & -0.28 \\
\hline Other Food & 0.136 & 0.84 & -0.08 & 0.04 & -0.01 & 0.01 & 0.06 & -0.02 & -1.02 & -0.01 & 0.03 \\
\hline Fuel & 0.054 & 0.58 & 0.60 & -0.21 & -0.16 & -0.03 & 0.14 & -0.06 & -0.03 & -0.82 & -0.42 \\
\hline Nonfood & 0.515 & 1.21 & -0.05 & -0.03 & -0.03 & 0.00 & -0.05 & -0.02 & 0.01 & -0.04 & -0.89 \\
\hline
\end{tabular}

Table 5

Price and Expenditure Elasticities from Urban Pooled Cross-sectional Model

\begin{tabular}{|c|c|c|c|c|c|c|c|c|c|c|c|}
\hline \multirow[b]{2}{*}{ Commodity } & \multirow[b]{2}{*}{$\begin{array}{l}\text { Budget } \\
\text { Share }\end{array}$} & \multirow[b]{2}{*}{$\begin{array}{l}\text { Expendi- } \\
\text { ture } \\
\text { Elasticity }\end{array}$} & \multicolumn{9}{|c|}{ Compensated Price Elasticity with Respect to Price of } \\
\hline & & & Wheat & Rice & Pulses & Dairy & Meat & Oils & $\begin{array}{l}\text { Other } \\
\text { Food }\end{array}$ & Fuel & Nonfood \\
\hline Wheat & 0.072 & 0.29 & -0.83 & 0.07 & 0.22 & -0.16 & -0.20 & 0.37 & 0.06 & 0.34 & -0.87 \\
\hline Rice & 0.019 & 0.84 & 0.26 & 0.22 & -0.48 & -1.03 & 1.49 & 0.27 & -0.58 & -0.66 & -0.48 \\
\hline Pulses & 0.020 & 0.43 & 0.80 & -0.46 & -0.39 & 0.50 & 0.66 & -0.81 & -0.20 & -0.39 & -0.75 \\
\hline Dairy & 0.086 & 1.01 & -0.14 & -0.22 & 0.11 & -1.78 & 0.28 & 0.18 & -0.03 & 0.18 & 0.43 \\
\hline Meat & 0.054 & 1.28 & -0.26 & 0.52 & 0.24 & 0.44 & -1.06 & -0.60 & -0.27 & -0.26 & 0.25 \\
\hline Oils & 0.044 & 0.53 & 0.61 & 0.12 & 0.37 & 0.34 & -0.74 & -1.02 & -0.10 & 0.08 & 0.06 \\
\hline Other Food & 0.136 & 0.83 & 0.03 & -0.08 & -0.03 & -0.02 & -0.11 & -0.03 & -0.81 & 0.05 & 0.01 \\
\hline Fuel & 0.054 & 0.57 & 0.45 & -0.23 & -0.13 & 0.28 & -0.26 & 0.07 & 0.11 & -0.77 & -0.52 \\
\hline Nonfood & 0.515 & 1.22 & -0.12 & -0.02 & -0.03 & 0.07 & 0.03 & 0.01 & 0.00 & -0.05 & -0.88 \\
\hline
\end{tabular}


In both sets of tables the elasticities are reported at the sample means. In general, the urban own-price elasticities are smaller in absolute value than the corresponding rural estimates. One exception, however, is the relatively large own-price elasticity for meat in both urban estimates. Urban fuel cross-price elasticities differ in sign and magnitude from rural estimates.

A major difference between the urban fixed-effect and cross-sectional estimates is in the magnitude of the dairy own-price elasticity as well as the cross-price elasticities of dairy consumption with changes in meat and nonfood prices. There is also a vast difference between the approaches in the estimation of responses to . changes in dalda and other oil prices. The range is wider than desirable for policy analysis. It may be that the price variation was too limited for accurate estimates in the urban fixed-effects approach.

\section{PARAMETERS FOR LOW-INCOME HOUSEHOLDS}

It has been observed that low-income households often respond to price changes in a manner that differs from that of the general population (Alderman 1986). To investigate this, the fixed-effects model was reestimated using only observations on households below the 25th percentile of total real expenditure per capita and the district mean values for that subsample. Since this subsample has less variation in expenditures than the total sample, the term for the square of the logarithm of total expenditures was dropped. The elasticities from that reestimation in the rural area are in Table 6. The results differ somewhat from what would be calculated using the parameters from the full sample in Appendix Table 1 along with the average budget shares of the lowest expenditure quartile, although this difference is often not pronounced. Note that for goods that are not luxuries, the AIDS model constrains own-price elasticities to be smaller in absolute value with lower expenditures unless the parameters are allowed to vary with income.

The most obvious difference between Table 1 and Table 6 is the appreciable own-price elasticity for meat consumption for poorer consumers. In general, many of the price parameters in the low-income households are higher in absolute value than those for the general population. This conforms to the general pattern observed in other countries, but contrasts with the pattern implied in the AIDS general framework. As the approach used here links the lowest quartile of a sample that was collected over four quarterly rounds, it differs from what might be observed with repeated observations of the same households. Such a study of the price responsiveness of low-income households remains a topic for further study. While a similar set of parameters for low-income urban consumers was estimated, they are not presented here. The urban poor did not exhibit noticeably different price response than the general population.

\begin{tabular}{|c|c|c|c|c|c|c|c|}
\hline $\begin{array}{l}\text { क्: } \\
\text { z }\end{array}$ & $\stackrel{\text { oे }}{\circ}$ & $\begin{array}{l}n \\
\infty \\
0 \\
i\end{array}$ & 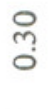 & $\stackrel{m}{i}$ & 요 & $\stackrel{0}{0}$ & b \\
\hline$\vec{\Phi}$ & $\begin{array}{l}\infty \\
\stackrel{0}{0} \\
\stackrel{1}{0}\end{array}$ & กั & $\frac{\circ}{0}$ & $\stackrel{\infty}{\sim}$ & 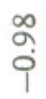 & o̊ & å \\
\hline 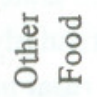 & ○’ & 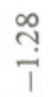 & ñ & $\stackrel{\circ}{\circ}$ & $\begin{array}{l}m \\
m \\
i\end{array}$ & $\begin{array}{l}\infty \\
\infty \\
0\end{array}$ & กิ \\
\hline$\sum_{\Sigma}^{\mathbb{J}}$ & $\frac{\infty}{i}$ & $\stackrel{g}{\text { co }}$ & $\stackrel{7}{\stackrel{I}{1}}$ & ஸे & $\stackrel{\stackrel{\infty}{ָ}}{i}$ & œ̊ & ra \\
\hline ڤึ & 우 & @o & 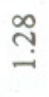 & $\stackrel{n}{i}$ & $\stackrel{\infty}{\circ}$ & $\ddot{\circ}$ & $\stackrel{\infty}{+}$ \\
\hline 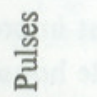 & $\begin{array}{l}\mathscr{0} \\
\stackrel{0}{1}\end{array}$ & $\stackrel{m}{\dot{q}}$ & $\begin{array}{l}\circ \\
\stackrel{0}{0} \\
\text { i }\end{array}$ & సి & 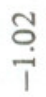 & $\begin{array}{l}0 \\
0 \\
0\end{array}$ & $\bar{m}$ \\
\hline$\ddot{\mathscr{Z}}$ & ঙे & ते & 웅 & $\frac{9}{0}$ & $\stackrel{ }{\stackrel{2}{-}}$ & 뭉 & in \\
\hline 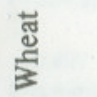 & 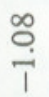 & స్ & ô & $=$ & ị & $\dot{0}$ & $\begin{array}{l}\text { กิ } \\
\text { 인 }\end{array}$ \\
\hline 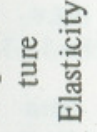 & $\stackrel{\text { J }}{\circ}$ & ふু & 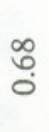 & $\stackrel{\infty}{\infty}$ & $\stackrel{8}{\sim}$ & $\begin{array}{l}\infty \\
\infty \\
0\end{array}$ & $\stackrel{2}{2}$ \\
\hline 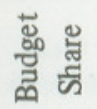 & $\frac{9}{0}$ & రి & 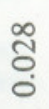 & $\frac{\overrightarrow{7}}{0}$ & กิ & $\frac{\mathrm{\sigma}}{0}$ & g \\
\hline & 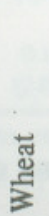 & $\stackrel{\ddot{g}}{\ddot{2}}$ & $\begin{array}{l}\mathscr{ٌ} \\
\frac{2}{3} \\
\ddot{2}\end{array}$ & 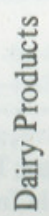 & $\stackrel{\mathbb{J}}{\mathbb{J}}$ & 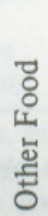 & $\bar{\Xi}$ \\
\hline
\end{tabular}




\section{CONCLUSIONS}

The rural and urban results are presented in separate tables for two reasons. First, when slope parameters differ among subsamples, joint estimations, even when weighted, do not give accurate average responses. Any projections for policy purposes that calculate changes in consumption separately by sector will likely be more accurate than those using aggregate data. ${ }^{6}$ Secondly, by disaggregating urban and rural sectors, one need not assume both sectors will face the same price and income changes following changes in government policy. This is particularly useful when one considers the effects of food price changes on the income of rural producers.

While these estimates may be of some use in policy analysis, the main result of the paper is to illustrate a methodology that can be readily applied to future data analysis. The results presented here indicate that plausible and detailed estimates of consumer response to price changes can be obtained using household expenditure surveys and published price series in a manner that does not require the assumptions of additive preferences. It is noted that a fixed-effects approach which sweeps out spatial long-run price differences can be employed as a replicated time series even over a limited period of four quarters. It is hoped that these results can be useful for a variety of planning purposes, although it is also hoped that improved accuracy can be obtained in the future by linking the $1984-85$ nationwide household expenditure survey or similar data sets when they become available. With greater price variation, it is likely that more accuracy can be obtained, especially if increased commodity breakdown is desired. The limited price variation for dalda or for non-rationed sugar in the data used here prevented satisfactory analysis of price responses important for current policy questions. The linking of more recent data sets should aid in the analysis of these and similar questions.
Appendix Table 1

Parameters for Rural Fixed-effect Model ( $\mathrm{t}$-values in parenthesis $)^{a}$

\begin{tabular}{|c|c|c|c|c|c|c|c|}
\hline \multirow[b]{2}{*}{$\begin{array}{l}\text { Independent } \\
\text { Variables }\end{array}$} & \multicolumn{7}{|c|}{ Dependent Variables } \\
\hline & WWheat & WRice & WPulse & WMeat & WDairy & $\begin{array}{l}\text { WOther } \\
\text { Food }\end{array}$ & WFuel \\
\hline Lexp & $\begin{array}{c}-25.815 \\
(-18.616)\end{array}$ & $\begin{array}{c}0.775 \\
(1.077)\end{array}$ & $\begin{array}{c}-1.492 \\
(-4.339)\end{array}$ & $\begin{array}{c}4.782 \\
(6.502)\end{array}$ & $\begin{array}{c}41.057 \\
(19.379)\end{array}$ & $\begin{array}{l}-1.844 \\
(-1.315)\end{array}$ & $\begin{array}{l}-1.561 \\
(-2.273)\end{array}$ \\
\hline$(\operatorname{Lexp})^{2}$ & $\begin{array}{c}1.789 \\
(12.920)\end{array}$ & $\begin{array}{c}-0.092 \\
(-1.274)\end{array}$ & $\begin{array}{c}0.042 \\
(1.237)\end{array}$ & $\begin{array}{c}-0.282 \\
(-3.881)\end{array}$ & $\begin{array}{c}-3.690 \\
(-17.448)\end{array}$ & $\begin{array}{c}-0.191 \\
(-1.365)\end{array}$ & $\begin{array}{c}-0.088 \\
(-1.281)\end{array}$ \\
\hline LWheatP & $\begin{array}{c}1.201 \\
(1.311)\end{array}$ & $\begin{array}{c}4.318 \\
(9.806)\end{array}$ & $\begin{array}{c}-0.551 \\
(-2.413)\end{array}$ & $\begin{array}{c}-0.618 \\
(-1.337)\end{array}$ & $\begin{array}{c}-1.765 \\
(-1.729)\end{array}$ & $\begin{array}{c}0.327 \\
(0.405)\end{array}$ & $\begin{array}{c}-0.232 \\
(-0.563)\end{array}$ \\
\hline LRiceP & $\begin{array}{c}4.318 \\
(9.806)\end{array}$ & $\begin{array}{l}-2.285 \\
(-4.051)\end{array}$ & $\begin{array}{l}-0.231 \\
(-0.875)\end{array}$ & $\begin{array}{c}1.642 \\
(3.383)\end{array}$ & $\begin{array}{c}1.629 \\
(2.295)\end{array}$ & $\begin{array}{c}-0.368 \\
(-2.029)\end{array}$ & $\begin{array}{l}-3.206 \\
(-8.702)\end{array}$ \\
\hline LPulseP & $\begin{array}{c}-0.551 \\
(-2.413)\end{array}$ & $\begin{array}{c}-0.231 \\
(-0.875)\end{array}$ & $\begin{array}{c}1.139 \\
(2.428)\end{array}$ & $\begin{array}{c}-1.376 \\
(-3.335)\end{array}$ & $\begin{array}{c}1.324 \\
(3.491)\end{array}$ & $\begin{array}{c}-0.439 \\
(-1.053)\end{array}$ & $\begin{array}{c}0.488 \\
(1.925)\end{array}$ \\
\hline LMeatP & $\begin{array}{c}-0.619 \\
(-1.337)\end{array}$ & $\begin{array}{c}1.642 \\
(3.383)\end{array}$ & $\begin{array}{l}-1.376 \\
(-3.335)\end{array}$ & $\begin{array}{c}2.843 \\
(-3.061)\end{array}$ & $\begin{array}{l}-2.301 \\
(-3.028)\end{array}$ & $\begin{array}{c}-1.349 \\
(-1.700)\end{array}$ & $\begin{array}{l}-1.812 \\
(-3.753)\end{array}$ \\
\hline LDairyP & $\begin{array}{c}-1.765 \\
(-1.729)\end{array}$ & $\begin{array}{c}1.630 \\
(2.295)\end{array}$ & $\begin{array}{c}1.324 \\
(3.491)\end{array}$ & $\begin{array}{l}-2.301 \\
(-3.028)\end{array}$ & $\begin{array}{c}-0.862 \\
(-0.391)\end{array}$ & $\begin{array}{c}1.953 \\
(1.491)\end{array}$ & $\begin{array}{c}1.171 \\
(1.774)\end{array}$ \\
\hline $\begin{array}{l}\text { LOther } \\
\text { FoodP }\end{array}$ & $\begin{array}{c}0.327 \\
(0.405)\end{array}$ & $\begin{array}{l}-1.368 \\
(-2.029)\end{array}$ & $\begin{array}{c}-0.439 \\
(-1.053)\end{array}$ & $\begin{array}{c}-1.349 \\
(-1.700)\end{array}$ & $\begin{array}{c}1.953 \\
(1.491)\end{array}$ & $\begin{array}{c}-0.706 \\
(-0.429)\end{array}$ & $\begin{array}{l}-0.581 \\
(0.930)\end{array}$ \\
\hline LFuelP & $\begin{array}{l}-0.232 \\
(-0.563)\end{array}$ & $\begin{array}{l}-3.206 \\
(-8.702)\end{array}$ & $\begin{array}{c}0.488 \\
(1.925)\end{array}$ & $\begin{array}{l}-1.812 \\
(-3.753)\end{array}$ & $\begin{array}{c}1.171 \\
(1.774)\end{array}$ & $\begin{array}{c}-0.581 \\
(-0.930)\end{array}$ & $\begin{array}{c}1.829 \\
(3.804)\end{array}$ \\
\hline LNonfoodP & $\begin{array}{l}-2.680 \\
(-2.063)\end{array}$ & $\begin{array}{c}-0.499 \\
(-0.490)\end{array}$ & $\begin{array}{c}-0.355 \\
(-0.500)\end{array}$ & $\begin{array}{c}2.972 \\
(2.366)\end{array}$ & $\begin{array}{l}-1.150 \\
(-0.533)\end{array}$ & $\begin{array}{c}2.165 \\
(1.143)\end{array}$ & $\begin{array}{c}2.342 \\
(2.445)\end{array}$ \\
\hline LHHSize & $\begin{array}{l}-0.477 \\
(-4.440)\end{array}$ & $\begin{array}{c}0.263 \\
(4.712)\end{array}$ & $\begin{array}{c}-0.519 \\
(-19.505)\end{array}$ & $\begin{array}{c}0.607 \\
(10.782)\end{array}$ & $\begin{array}{c}1.662 \\
(10.126)\end{array}$ & $\begin{array}{c}-2.186 \\
(-20.129)\end{array}$ & $\begin{array}{c}-1.788 \\
(-33.619)\end{array}$ \\
\hline CShare & $\begin{array}{c}-4.300 \\
(-12.466)\end{array}$ & $\begin{array}{c}-0.311 \\
(-1.878)\end{array}$ & $\begin{array}{c}-0.233 \\
(-2.938)\end{array}$ & $\begin{array}{c}1.014 \\
(6.056)\end{array}$ & $\begin{array}{c}1.003 \\
(2.057)\end{array}$ & $\begin{array}{c}0.932 \\
(2.886)\end{array}$ & $\begin{array}{c}-0.256 \\
(-1.621)\end{array}$ \\
\hline RD1 & $\begin{array}{c}0.889 \\
(4.432)\end{array}$ & $\begin{array}{c}-0.322 \\
(-2.453)\end{array}$ & $\begin{array}{c}0.206 \\
(2.266)\end{array}$ & $\begin{array}{c}0.230 \\
(1.471)\end{array}$ & $\begin{array}{c}0.539 \\
(1.943)\end{array}$ & $\begin{array}{c}-0.778 \\
(-2.697)\end{array}$ & $\begin{array}{c}0.536 \\
(4.391)\end{array}$ \\
\hline RD2 & $\begin{array}{c}-0.117 \\
(-0.797)\end{array}$ & $\begin{array}{c}-0.516 \\
(-5.211)\end{array}$ & $\begin{array}{c}-0.004 \\
(-0.069)\end{array}$ & $\begin{array}{c}-0.458 \\
(-4.044)\end{array}$ & $\begin{array}{c}-0.249 \\
(-1.138)\end{array}$ & $\begin{array}{c}0.616 \\
(2.823)\end{array}$ & $\begin{array}{l}-0.055 \\
(-0.607)\end{array}$ \\
\hline RD3 & $\begin{array}{c}-0.624 \\
(-3.195)\end{array}$ & $\begin{array}{c}0.586 \\
(4.520)\end{array}$ & $\begin{array}{c}-0.091 \\
(-1.194)\end{array}$ & $\begin{array}{c}0.383 \\
(2.586)\end{array}$ & $\begin{array}{c}-0.624 \\
(-2.266)\end{array}$ & $\begin{array}{c}0.475 \\
(1.608)\end{array}$ & $\begin{array}{c}-0.170 \\
(-1.409)\end{array}$ \\
\hline RD4 & $\begin{array}{c}-0.099 \\
(-0.742)\end{array}$ & $\begin{array}{c}0.195 \\
(2.034) \\
\end{array}$ & $\begin{array}{c}-0.092 \\
(-1.182)\end{array}$ & $\begin{array}{c}-0.144 \\
(-1.251)\end{array}$ & $\begin{array}{c}0.299 \\
(1.460) \\
\end{array}$ & $\begin{array}{c}-0.278 \\
(-1.490)\end{array}$ & $\begin{array}{l}-0.272 \\
(-3.171)\end{array}$ \\
\hline
\end{tabular}


Parameters for Urban Fixed-effects Model ( $\mathrm{t}$-values in parenthesis)

\begin{tabular}{|c|c|c|c|c|c|c|c|}
\hline \multirow[b]{2}{*}{$\begin{array}{l}\text { Independent } \\
\text { Variables }\end{array}$} & \multicolumn{7}{|c|}{ Dependent Variables } \\
\hline & WWheat & WRice & WPulse & WMeat & WDairy & $\begin{array}{l}\text { WOther } \\
\text { Food }\end{array}$ & WFuel \\
\hline Lexp & $\begin{array}{c}-29.519 \\
(-20.410)\end{array}$ & $\begin{array}{c}2.525 \\
(3.160)\end{array}$ & $\begin{array}{c}-1.024 \\
(-2.873)\end{array}$ & $\begin{array}{c}4.643 \\
(6.052)\end{array}$ & $\begin{array}{c}38.181 \\
(17.573)\end{array}$ & $\begin{array}{c}2.060 \\
(1.395)\end{array}$ & $\begin{array}{l}-0.563 \\
(-0.786)\end{array}$ \\
\hline$(\operatorname{Lexp})^{2}$ & $\begin{array}{c}2.124 \\
(14.686)\end{array}$ & $\begin{array}{c}-0.257 \\
(-3.218)\end{array}$ & $\begin{array}{c}-0.001 \\
(-0.023)\end{array}$ & $\begin{array}{c}-0.278 \\
(-3.628)\end{array}$ & $\begin{array}{c}-3.462 \\
(-15.935)\end{array}$ & $\begin{array}{c}-0.523 \\
(-3.543)\end{array}$ & $\begin{array}{l}-0.178 \\
(-2.494)\end{array}$ \\
\hline LWheatP & $\begin{array}{c}-3.357 \\
(-4.744)\end{array}$ & $\begin{array}{c}2.626 \\
(8.684)\end{array}$ & $\begin{array}{c}-0.345 \\
(-1.759)\end{array}$ & $\begin{array}{c}-0.214 \\
(-0.546)\end{array}$ & $\begin{array}{c}-10.538 \\
(-13.872)\end{array}$ & $\begin{array}{c}5.285 \\
(8.900)\end{array}$ & $\begin{array}{l}-0.052 \\
(-0.186)\end{array}$ \\
\hline LRiceP & $\begin{array}{c}2.626 \\
(8.684)\end{array}$ & $\begin{array}{c}1.862 \\
(7.571)\end{array}$ & $\begin{array}{c}-0.826 \\
(-6.875)\end{array}$ & $\begin{array}{c}5.548 \\
(23.794)\end{array}$ & $\begin{array}{c}-2.353 \\
(-5.118)\end{array}$ & $\begin{array}{c}4.048 \\
(11.496)\end{array}$ & $\begin{array}{l}-2.020 \\
(-12.055)\end{array}$ \\
\hline LPulseP & $\begin{array}{c}-0.345 \\
(-1.759)\end{array}$ & $\begin{array}{c}-0.826 \\
(-6.875)\end{array}$ & $\begin{array}{c}1.451 \\
(4.135)\end{array}$ & $\begin{array}{c}-1.122 \\
(-3.881)\end{array}$ & $\begin{array}{c}0.755 \\
(2.557)\end{array}$ & $\begin{array}{c}-0.515 \\
(-1.955)\end{array}$ & $\begin{array}{c}-0.639 \\
(-5.357)\end{array}$ \\
\hline LMeatP & $\begin{array}{c}-0.214 \\
(-0.546)\end{array}$ & $\begin{array}{c}5.548 \\
(23.794)\end{array}$ & $\begin{array}{c}-1.122 \\
(-3.881)\end{array}$ & $\begin{array}{c}3.609 \\
(6.053)\end{array}$ & $\begin{array}{c}8.034 \\
(13.844)\end{array}$ & $\begin{array}{c}-9.040 \\
(-18.389)\end{array}$ & $\begin{array}{c}-4.056 \\
(-17.569)\end{array}$ \\
\hline LDairyP & $\begin{array}{c}-10.538 \\
(-13.872)\end{array}$ & $\begin{array}{c}-2.353 \\
(-5.118)\end{array}$ & $\begin{array}{c}0.755 \\
(2.557)\end{array}$ & $\begin{array}{c}8.034 \\
(13.844)\end{array}$ & $\begin{array}{c}-26.841 \\
(-17.800)\end{array}$ & $\begin{array}{c}18.153 \\
(19.806)\end{array}$ & $\begin{array}{c}2.454 \\
(5.817)\end{array}$ \\
\hline $\begin{array}{l}\text { LOther } \\
\text { FoodP }\end{array}$ & $\begin{array}{c}5.285 \\
(8.900)\end{array}$ & $\begin{array}{c}4.048 \\
(11.496)\end{array}$ & $\begin{array}{c}-0.515 \\
(-1.955)\end{array}$ & $\begin{array}{c}-9.040 \\
(-18.389)\end{array}$ & $\begin{array}{c}18.153 \\
(19.806)\end{array}$ & $\begin{array}{c}4.858 \\
(4.799)\end{array}$ & $\begin{array}{c}6.264 \\
(18.071)\end{array}$ \\
\hline LFuelP & $\begin{array}{c}-0.052 \\
(-0.186)\end{array}$ & $\begin{array}{c}-2.020 \\
(-12.055)\end{array}$ & $\begin{array}{c}-0.639 \\
(-5.357)\end{array}$ & $\begin{array}{c}-4.056 \\
(-17.569)\end{array}$ & $\begin{array}{c}2.454 \\
(5.817)\end{array}$ & $\begin{array}{c}6.264 \\
(18.071)\end{array}$ & $\begin{array}{c}2.928 \\
(12.943)\end{array}$ \\
\hline LNonfoodP & $\begin{array}{c}6.595 \\
(7.738)\end{array}$ & $\begin{array}{c}-8.885 \\
(-18.357)\end{array}$ & $\begin{array}{c}1.240 \\
(3.497)\end{array}$ & $\begin{array}{c}-2.759 \\
(-3.752)\end{array}$ & $\begin{array}{l}10.336 \\
(8.095)\end{array}$ & $\begin{array}{c}-29.054 \\
(-28.117)\end{array}$ & $\begin{array}{c}-4.879 \\
(-10.448)\end{array}$ \\
\hline LHHSize & $\begin{array}{c}-0.688 \\
(-6.132)\end{array}$ & $\begin{array}{c}0.353 \\
(5.693)\end{array}$ & $\begin{array}{c}-0.549 \\
(-19.897)\end{array}$ & $\begin{array}{c}0.679 \\
(11.420)\end{array}$ & $\begin{array}{c}1.356 \\
(8.049)\end{array}$ & $\begin{array}{c}-2.080 \\
(-18.174)\end{array}$ & $\begin{array}{c}-1.828 \\
(-32.937)\end{array}$ \\
\hline CShare & $\begin{array}{c}-4.753 \\
(-14.161)\end{array}$ & $\begin{array}{c}-0.158 \\
(-0.852)\end{array}$ & $\begin{array}{c}-0.172 \\
(-2.081)\end{array}$ & $\begin{array}{c}0.922 \\
(5.185)\end{array}$ & $\begin{array}{c}0.308 \\
(0.610)\end{array}$ & $\begin{array}{c}1.513 \\
(4.417)\end{array}$ & $\begin{array}{c}-0.084 \\
(-0.506)\end{array}$ \\
\hline RD1 & $\begin{array}{c}99.003 \\
(24.523)\end{array}$ & $\begin{array}{c}9.501 \\
(4.322)\end{array}$ & $\begin{array}{c}7.130 \\
(6.758)\end{array}$ & $\begin{array}{c}-6.111 \\
(-2.763)\end{array}$ & $\begin{array}{c}-122.937 \\
(20.777)\end{array}$ & $\begin{array}{c}70.350 \\
(17.093)\end{array}$ & $\begin{array}{c}22.505 \\
(11.382)\end{array}$ \\
\hline RD2 & $\begin{array}{c}97.508 \\
(24.060)\end{array}$ & $\begin{array}{c}8.961 \\
(4.069)\end{array}$ & $\begin{array}{c}6.933 \\
(6.541)\end{array}$ & $\begin{array}{c}-6.419 \\
(-2.894)\end{array}$ & $\begin{array}{l}-124.787 \\
(-21.056)\end{array}$ & $\begin{array}{c}71.893 \\
(17.445)\end{array}$ & $\begin{array}{l}21.563 \\
(10.883)\end{array}$ \\
\hline RD3 & $\begin{array}{c}94.825 \\
(23.246)\end{array}$ & $\begin{array}{c}8.491 \\
(3.850)\end{array}$ & $\begin{array}{c}6.947 \\
(6.536)\end{array}$ & $\begin{array}{l}-3.171 \\
(-1.429)\end{array}$ & $\begin{array}{l}-130.817 \\
(-22.043)\end{array}$ & $\begin{array}{c}69.989 \\
(17.034)\end{array}$ & $\begin{array}{l}19.121 \\
(9.645)\end{array}$ \\
\hline RD4 & $\begin{array}{c}95.309 \\
(23.371)\end{array}$ & $\begin{array}{c}9.063 \\
(4.099)\end{array}$ & $\begin{array}{c}6.844 \\
(6.380)\end{array}$ & $\begin{array}{c}-3.621 \\
(-1.625)\end{array}$ & $\begin{array}{l}-129.214 \\
(-21.727)\end{array}$ & $\begin{array}{c}70.993 \\
(17.223)\end{array}$ & $\begin{array}{l}19.709 \\
(9.919)\end{array}$ \\
\hline
\end{tabular}

\begin{tabular}{|c|c|c|c|c|c|c|c|c|}
\hline \multirow[b]{2}{*}{$\begin{array}{l}\text { Independent } \\
\text { Variables }\end{array}$} & \multicolumn{8}{|c|}{ Dependent Variables } \\
\hline & WWheat & WRice & WPulse & WMeat & WDairy & WOils & $\begin{array}{l}\text { WOther } \\
\text { Food }\end{array}$ & WFuel \\
\hline Lexp & $\begin{array}{c}-14.112 \\
(-19.443)\end{array}$ & $\begin{array}{c}1.272 \\
(3.867)\end{array}$ & $\begin{array}{c}-1.105 \\
(-5.330)\end{array}$ & $\begin{array}{c}10.689 \\
(20.011)\end{array}$ & $\begin{array}{c}14.103 \\
(18.139)\end{array}$ & $\begin{array}{l}-3.194 \\
(9.937)\end{array}$ & $\begin{array}{c}-0.743 \\
(-0.942)\end{array}$ & $\begin{array}{l}-2.111 \\
(-5.271)\end{array}$ \\
\hline$(L \exp )^{2}$ & $\begin{array}{c}0.879 \\
(13.584)\end{array}$ & $\begin{array}{c}-0.149 \\
(-5.086)\end{array}$ & $\begin{array}{c}-0.005 \\
(-0.290)\end{array}$ & $\begin{array}{c}-0.848 \\
(-17.801)\end{array}$ & $\begin{array}{c}-1.280 \\
(-18.461)\end{array}$ & $\begin{array}{c}0.098 \\
(3.410)\end{array}$ & $\begin{array}{c}0.134 \\
(-1.900)\end{array}$ & $\begin{array}{l}-0.012 \\
(-0.358)\end{array}$ \\
\hline LWheatP & $\begin{array}{c}4.982 \\
(5.759)\end{array}$ & $\begin{array}{c}0.806 \\
(2.336)\end{array}$ & $\begin{array}{c}1.376 \\
(5.166)\end{array}$ & $\begin{array}{c}-2.697 \\
(-4.230)\end{array}$ & $\begin{array}{l}-3.669 \\
(-7.512)\end{array}$ & $\begin{array}{c}-0.436 \\
(-0.776)\end{array}$ & $\begin{array}{c}-1.116 \\
(-4.050)\end{array}$ & $\begin{array}{c}3.234 \\
(8.623)\end{array}$ \\
\hline LRiceP & $\begin{array}{c}0.806 \\
(2.336)\end{array}$ & $\begin{array}{c}0.131 \\
(0.510)\end{array}$ & $\begin{array}{c}-0.045 \\
(-0.309)\end{array}$ & $\begin{array}{c}0.339 \\
(1.047)\end{array}$ & $\begin{array}{c}0.795 \\
(3.085)\end{array}$ & $\begin{array}{c}-0.055 \\
(-0.226)\end{array}$ & $\begin{array}{c}0.608 \\
(4.465)\end{array}$ & $\begin{array}{l}-1.151 \\
(-5.758)\end{array}$ \\
\hline LPulseP & $\begin{array}{c}1.376 \\
(5.166)\end{array}$ & $\begin{array}{r}-0.045) \\
(-0.309)\end{array}$ & $\begin{array}{c}1.329 \\
(6.882)\end{array}$ & $\begin{array}{c}-0.347 \\
(-1.203)\end{array}$ & $\begin{array}{c}0.487 \\
(2.855)\end{array}$ & $\begin{array}{c}-0.097 \\
(-0.345)\end{array}$ & $\begin{array}{c}-0.086 \\
(-1.024)\end{array}$ & $\begin{array}{c}-0.869 \\
(-5.198)\end{array}$ \\
\hline LMeatP & $\begin{array}{l}-2.697 \\
(-4.230)\end{array}$ & $\begin{array}{c}0.339 \\
(1.047)\end{array}$ & $\begin{array}{c}-0.347 \\
(-1.203)\end{array}$ & $\begin{array}{c}-0.048 \\
(-0.054)\end{array}$ & $\begin{array}{c}0.017 \\
(0.041)\end{array}$ & $\begin{array}{c}-1.419 \\
(-2.678)\end{array}$ & $\begin{array}{c}0.762 \\
(3.658)\end{array}$ & $\begin{array}{c}0.749 \\
(1.842)\end{array}$ \\
\hline LDairyP & $\begin{array}{l}-3.669 \\
(-7.512)\end{array}$ & $\begin{array}{c}0.795 \\
(3.085)\end{array}$ & $\begin{array}{c}0.487 \\
(2.855)\end{array}$ & $\begin{array}{c}0.017 \\
(0.041)\end{array}$ & $\begin{array}{c}2.077 \\
(3.293)\end{array}$ & $\begin{array}{c}-0.097 \\
(-0.346)\end{array}$ & $\begin{array}{c}0.169 \\
(0.604)\end{array}$ & $\begin{array}{l}-0.154 \\
(-0.545)\end{array}$ \\
\hline LDaldap & $\begin{array}{c}-0.436 \\
(-0.776)\end{array}$ & $\begin{array}{c}-0.055 \\
(-0.226)\end{array}$ & $\begin{array}{c}-0.096 \\
(-0.345)\end{array}$ & $\begin{array}{c}-1.419 \\
(-2.678)\end{array}$ & $\begin{array}{c}-0.097 \\
(-0.346)\end{array}$ & $\begin{array}{c}4.025 \\
(4.123)\end{array}$ & $\begin{array}{c}-0.321 \\
(-2.413)\end{array}$ & $\begin{array}{l}-0.345 \\
(-1.133)\end{array}$ \\
\hline $\begin{array}{l}\text { LOther } \\
\text { Food P }\end{array}$ & $\begin{array}{c}-1.116 \\
(-4.050)\end{array}$ & $\begin{array}{c}0.608 \\
(4.465)\end{array}$ & $\begin{array}{c}-0.086 \\
(-1.024)\end{array}$ & $\begin{array}{c}0.762 \\
(3.658)\end{array}$ & $\begin{array}{c}0.169 \\
(0.604)\end{array}$ & $\begin{array}{c}-0.321 \\
(-2.413)\end{array}$ & $\begin{array}{c}-0.297 \\
(-1.041)\end{array}$ & $\begin{array}{c}-0.169 \\
(-1.153)\end{array}$ \\
\hline LFuelP & $\begin{array}{c}3.234 \\
(8.623)\end{array}$ & $\begin{array}{c}-1.151 \\
(-5.758)\end{array}$ & $\begin{array}{c}-0.869 \\
(-5.198)\end{array}$ & $\begin{array}{c}0.749 \\
(1.842)\end{array}$ & $\begin{array}{c}-0.154 \\
(-0.545)\end{array}$ & $\begin{array}{c}-0.345 \\
(-1.133)\end{array}$ & $\begin{array}{c}-0.169 \\
(-1.153)\end{array}$ & $\begin{array}{c}0.994 \\
(3.230)\end{array}$ \\
\hline LNonfoodP & $\begin{array}{l}-2.480 \\
(-4.671)\end{array}$ & $\begin{array}{l}-1.429 \\
(-5.719)\end{array}$ & $\begin{array}{c}-1.750 \\
(-7.875)\end{array}$ & $\begin{array}{c}2.644 \\
(5.265)\end{array}$ & $\begin{array}{c}0.376 \\
(0.826)\end{array}$ & $\begin{array}{l}-1.255 \\
(-2.032)\end{array}$ & $\begin{array}{c}0.449 \\
(1.297)\end{array}$ & $\begin{array}{c}-2.290 \\
(-6.732)\end{array}$ \\
\hline LHHSize & $\begin{array}{c}0.979 \\
(13.891)\end{array}$ & $\begin{array}{c}0.502 \\
(15.721)\end{array}$ & $\begin{array}{c}-0.032 \\
(-1.595)\end{array}$ & $\begin{array}{c}1.617 \\
(31.154)\end{array}$ & $\begin{array}{c}1.337 \\
(17.698)\end{array}$ & $\begin{array}{c}0.122 \\
(3.912)\end{array}$ & $\begin{array}{c}1.215 \\
(15.848)\end{array}$ & $\begin{array}{c}-0.585 \\
(-15.034)\end{array}$ \\
\hline CShare & $\begin{array}{c}-2.618 \\
(-11.638)\end{array}$ & $\begin{array}{c}-0.158 \\
(-1.550)\end{array}$ & $\begin{array}{c}-0.372 \\
(-5.795)\end{array}$ & $\begin{array}{c}0.699 \\
(4.225)\end{array}$ & $\begin{array}{c}2.708 \\
(11.238)\end{array}$ & $\begin{array}{c}-0.694 \\
(-6.972)\end{array}$ & $\begin{array}{c}1.061 \\
(4.338)\end{array}$ & $\begin{array}{c}-0.009 \\
(-0.080)\end{array}$ \\
\hline RD1 & $\begin{array}{c}0.902 \\
(5.729)\end{array}$ & $\begin{array}{c}0.454 \\
(5.985)\end{array}$ & $\begin{array}{c}0.233 \\
(4.950)\end{array}$ & $\begin{array}{c}1.017 \\
(8.526)\end{array}$ & $\begin{array}{c}0.174 \\
(1.052)\end{array}$ & $\begin{array}{c}0.329 \\
(4.401)\end{array}$ & $\begin{array}{c}-1.002 \\
(-5.837)\end{array}$ & $\begin{array}{c}0.129 \\
(1.504)\end{array}$ \\
\hline RD2 & $\begin{array}{l}-0.070 \\
(-1.016)\end{array}$ & $\begin{array}{c}0.076 \\
(2.344)\end{array}$ & $\begin{array}{c}0.021 \\
(1.011)\end{array}$ & $\begin{array}{c}0.062 \\
(1.201)\end{array}$ & $\begin{array}{c}0.084 \\
(1.173)\end{array}$ & $\begin{array}{c}0.012 \\
(0.362)\end{array}$ & $\begin{array}{c}0.204 \\
(2.936)\end{array}$ & $\begin{array}{c}0.028 \\
(0.750)\end{array}$ \\
\hline RD3 & $\begin{array}{c}-0.296 \\
(-1.602)\end{array}$ & $\begin{array}{c}-0.459 \\
(-5.152)\end{array}$ & $\begin{array}{c}-0.209 \\
(-3.816)\end{array}$ & $\begin{array}{l}-0.638 \\
(-4.620)\end{array}$ & $\begin{array}{c}-0.057 \\
(-0.304)\end{array}$ & $\begin{array}{c}-0.227 \\
(-2.558)\end{array}$ & $\begin{array}{c}0.786 \\
(4.158)\end{array}$ & $\begin{array}{c}-0.112 \\
(-1.127)\end{array}$ \\
\hline RD4 & $\begin{array}{c}-0.222 \\
(-1.356)\end{array}$ & $\begin{array}{c}-0.281 \\
(-3.492)\end{array}$ & $\begin{array}{c}-0.086 \\
(-1.633)\end{array}$ & $\begin{array}{c}-0.609 \\
(-4.656)\end{array}$ & $\begin{array}{c}-0.447 \\
(-2.672)\end{array}$ & $\begin{array}{c}-0.117 \\
(-1.373)\end{array}$ & $\begin{array}{c}-0.599 \\
(-3.723)\end{array}$ & $\begin{array}{c}-0.111 \\
(-1.225)\end{array}$ \\
\hline
\end{tabular}


Appendix Table 4

Parameters for Urban Cross-sectional/Time-series Model ( $t$-values in parenthesis)

\begin{tabular}{|c|c|c|c|c|c|c|c|c|}
\hline \multirow[b]{2}{*}{$\begin{array}{l}\text { Independent } \\
\text { Variables }\end{array}$} & \multicolumn{8}{|c|}{ Dependent Variables } \\
\hline & WWheat & WRice & WPulse & WMeat & WDairy & wOils & $\begin{array}{l}\text { WOther } \\
\text { Food }\end{array}$ & WFuel \\
\hline Lexp & $\begin{array}{c}-16.505 \\
(-21.946)\end{array}$ & $\begin{array}{c}1.506 \\
(4.491)\end{array}$ & $\begin{array}{c}-1.045 \\
(-5.044)\end{array}$ & $\begin{array}{c}10.445 \\
(19.458)\end{array}$ & $\begin{array}{c}11.849 \\
(15.017)\end{array}$ & $\begin{array}{l}-2.705 \\
(-8.406)\end{array}$ & $\begin{array}{l}-1.313 \\
(-1.668)\end{array}$ & $\begin{array}{c}-2.404 \\
(-5.931)\end{array}$ \\
\hline$(\operatorname{Lexp})^{2}$ & $\begin{array}{c}1.066 \\
(15.847)\end{array}$ & $\begin{array}{c}-0.169 \\
(-5.644)\end{array}$ & $\begin{array}{c}-0.009 \\
(-0.498)\end{array}$ & $\begin{array}{c}-0.834 \\
(-17.373)\end{array}$ & $\begin{array}{c}-1.099 \\
(-15.578)\end{array}$ & $\begin{array}{c}0.059 \\
(2.036)\end{array}$ & $\begin{array}{c}-0.091 \\
(-1.286)\end{array}$ & $\begin{array}{c}0.008 \\
(0.233)\end{array}$ \\
\hline LWheatP & $\begin{array}{l}1.245 \\
(1.865)\end{array}$ & $\begin{array}{c}0.495 \\
(2.070)\end{array}$ & $\begin{array}{c}1.614 \\
(7.531)\end{array}$ & $\begin{array}{c}-1.457 \\
(-2.816)\end{array}$ & $\begin{array}{l}-1.194 \\
(-3.471)\end{array}$ & $\begin{array}{c}2.697 \\
(7.287)\end{array}$ & $\begin{array}{c}0.451 \\
(1.856)\end{array}$ & $\begin{array}{c}2.442 \\
(9.057)\end{array}$ \\
\hline LRiceP & $\begin{array}{l}0.495 \\
(2.070)\end{array}$ & $\begin{array}{c}2.312 \\
(14.677)\end{array}$ & $\begin{array}{c}-0.924 \\
(-9.624)\end{array}$ & $\begin{array}{c}2.827 \\
(13.285)\end{array}$ & $\begin{array}{c}-1.969 \\
(-10.784)\end{array}$ & $\begin{array}{c}0.519 \\
(3.526)\end{array}$ & $\begin{array}{c}-1.118 \\
(-9.490)\end{array}$ & $\begin{array}{l}-1.227 \\
(-9.863)\end{array}$ \\
\hline LPulseP & $\begin{array}{c}1.614 \\
(7.531)\end{array}$ & $\begin{array}{c}-0.923 \\
(-9.624)\end{array}$ & $\begin{array}{c}1.219 \\
(7.084)\end{array}$ & $\begin{array}{c}1.313 \\
(5.712)\end{array}$ & $\begin{array}{c}0.999 \\
(7.574)\end{array}$ & $\begin{array}{l}-1.626 \\
(-8.017)\end{array}$ & $\begin{array}{c}-0.412 \\
(-5.152)\end{array}$ & $\begin{array}{c}-0.691 \\
(-5.640)\end{array}$ \\
\hline LMeatP & $\begin{array}{l}-1.457 \\
(-2.816)\end{array}$ & $\begin{array}{c}2.827 \\
(13.285)\end{array}$ & $\begin{array}{c}1.313 \\
(5.712)\end{array}$ & $\begin{array}{c}-0.303 \\
(-0.450)\end{array}$ & $\begin{array}{c}2.398 \\
(7.910)\end{array}$ & $\begin{array}{l}-3.240 \\
(-8.607)\end{array}$ & $\begin{array}{c}-1.478 \\
(-7.540)\end{array}$ & $\begin{array}{c}-1.428 \\
(-5.367)\end{array}$ \\
\hline LDairyP & $\begin{array}{c}-1.194 \\
(-3.471)\end{array}$ & $\begin{array}{c}-1.969 \\
(-10.784)\end{array}$ & $\begin{array}{c}0.999 \\
(7.574)\end{array}$ & $\begin{array}{c}2.398 \\
(7.910)\end{array}$ & $\begin{array}{c}-6.752 \\
(-16.874)\end{array}$ & $\begin{array}{c}1.537 \\
(7.275)\end{array}$ & $\begin{array}{c}-0.271 \\
(-1.177)\end{array}$ & $\begin{array}{c}1.526 \\
(8.224)\end{array}$ \\
\hline LDaldap & $\begin{array}{c}2.697 \\
(7.287)\end{array}$ & $\begin{array}{c}0.519 \\
(3.526)\end{array}$ & $\begin{array}{l}-1.626 \\
(-8.017)\end{array}$ & $\begin{array}{c}-3.240 \\
(-8.607)\end{array}$ & $\begin{array}{c}1.537 \\
(7.275)\end{array}$ & $\begin{array}{l}-0.107 \\
(-0.222)\end{array}$ & $\begin{array}{c}-0.448 \\
(-3.603)\end{array}$ & $\begin{array}{c}0.371 \\
(1.810)\end{array}$ \\
\hline $\begin{array}{l}\text { LOther } \\
\text { FoodP }\end{array}$ & $\begin{array}{c}0.451 \\
(1.856)\end{array}$ & $\begin{array}{c}-1.118 \\
(-9.490)\end{array}$ & $\begin{array}{c}-0.412 \\
(-5.152)\end{array}$ & $\begin{array}{c}-1.478 \\
(-7.540)\end{array}$ & $\begin{array}{c}-0.271 \\
(-1.177)\end{array}$ & $\begin{array}{c}-0.448 \\
(-3.603)\end{array}$ & $\begin{array}{c}2.506 \\
(10.705)\end{array}$ & $\begin{array}{c}0.617 \\
(4.661)\end{array}$ \\
\hline LFuelP & $\begin{array}{c}2.442 \\
(9.057)\end{array}$ & $\begin{array}{l}-1.227 \\
(-9.863)\end{array}$ & $\begin{array}{c}-0.691 \\
(-5.640)\end{array}$ & $\begin{array}{c}-1.429 \\
(-5.367)\end{array}$ & $\begin{array}{c}1.526 \\
(8.224)\end{array}$ & $\begin{array}{c}0.371 \\
(1.810)\end{array}$ & $\begin{array}{c}0.617 \\
(4.661)\end{array}$ & $\begin{array}{c}1.213 \\
(6.182)\end{array}$ \\
\hline LNonfoodP & $\begin{array}{c}-6.293) \\
(-14.225)\end{array}$ & $\begin{array}{c}-0.916 \\
(-4.821)\end{array}$ & $\begin{array}{c}-1.493 \\
(-8.055)\end{array}$ & $\begin{array}{c}1.368 \\
(3.383)\end{array}$ & $\begin{array}{l}3.725 \\
(9.936)\end{array}$ & $\begin{array}{c}0.298 \\
(0.762)\end{array}$ & $\begin{array}{c}0.154 \\
(0.496)\end{array}$ & $\begin{array}{c}-2.821 \\
(-11.268)\end{array}$ \\
\hline LHHSize & $\begin{array}{c}0.896 \\
(12.195)\end{array}$ & $\begin{array}{c}0.483 \\
(14.756)\end{array}$ & $\begin{array}{c}-0.043 \\
(-2.112)\end{array}$ & $\begin{array}{c}1.619 \\
(30.889)\end{array}$ & $\begin{array}{c}1.195 \\
(15.520)\end{array}$ & $\begin{array}{c}0.166 \\
(5.285)\end{array}$ & $\begin{array}{c}1.303 \\
(16.957)\end{array}$ & $\begin{array}{c}-0.566 \\
(-14.283)\end{array}$ \\
\hline CShare & $\begin{array}{c}-2.703 \\
(-11.484)\end{array}$ & $\begin{array}{c}-0.172 \\
(-1.644)\end{array}$ & $\begin{array}{c}-0.401 \\
(-6.188)\end{array}$ & $\begin{array}{c}0.749 \\
(4.464)\end{array}$ & $\begin{array}{c}2.544 \\
(10.307)\end{array}$ & $\begin{array}{l}-0.657 \\
(-6.531)\end{array}$ & $\begin{array}{c}1.075 \\
(4.362)\end{array}$ & $\begin{array}{c}0.043 \\
(0.344)\end{array}$ \\
\hline RD1 & $\begin{array}{l}71.625 \\
(28.527)\end{array}$ & $\begin{array}{c}-0.703 \\
(-0.658)\end{array}$ & $\begin{array}{c}14.329 \\
(19.868)\end{array}$ & $\begin{array}{c}-23.268 \\
(-12.671)\end{array}$ & $\begin{array}{c}-38.126 \\
(-15.965)\end{array}$ & $\begin{array}{c}23.479 \\
(19.950)\end{array}$ & $\begin{array}{l}20.035 \\
(8.752)\end{array}$ & $\begin{array}{c}26.365 \\
(20.764)\end{array}$ \\
\hline RD2 & $\begin{array}{c}70.047 \\
(28.123)\end{array}$ & $\begin{array}{c}-0.654 \\
(-0.616)\end{array}$ & $\begin{array}{c}14.112 \\
(19.684)\end{array}$ & $\begin{array}{c}-23.822 \\
(-13.034)\end{array}$ & $\begin{array}{c}-38.256 \\
(-16.134)\end{array}$ & $\begin{array}{c}23.123 \\
(19.777)\end{array}$ & $\begin{array}{l}20.318 \\
(8.936)\end{array}$ & $\begin{array}{c}26.049 \\
(20.665)\end{array}$ \\
\hline RD3 & $\begin{array}{c}68.579 \\
(27.050)\end{array}$ & $\begin{array}{c}0.124 \\
(0.115)\end{array}$ & $\begin{array}{c}14.203 \\
(19.932)\end{array}$ & $\begin{array}{c}-22.612 \\
(-12.132)\end{array}$ & $\begin{array}{c}-37.927 \\
(-15.718)\end{array}$ & $\begin{array}{c}23.037 \\
(19.367)\end{array}$ & $\begin{array}{l}18.992 \\
(8.252)\end{array}$ & $\begin{array}{c}25.250 \\
(19.738)\end{array}$ \\
\hline RD4 & $\begin{array}{c}69.269 \\
(27.448)\end{array}$ & $\begin{array}{c}0.136 \\
(0.126)\end{array}$ & $\begin{array}{c}14.341 \\
(19.743)\end{array}$ & $\begin{array}{c}-22.509 \\
(-12.175)\end{array}$ & $\begin{array}{c}-38.641 \\
(-16.030)\end{array}$ & $\begin{array}{c}22.925 \\
(19.430)\end{array}$ & $\begin{array}{l}17.627 \\
(7.663)\end{array}$ & $\begin{array}{c}25.299 \\
(19.827)\end{array}$ \\
\hline
\end{tabular}

\section{REFERENCES}

Ahmad, Ehtisham, H. M. Leung and Nicholas Stern (1986). Demand Response in Pakistan: A Modification of the Linear Expenditure System for 1976. London: London School of Economics.

Ahmad, Ehtisham, H. M. Leung and Nicholas Stern (1986a). The Demand for Wheat under Nonlinear Pricing in Pakistan. London: London School of Economics.

Alderman, Harold (1986). "The Effect of Food Price and Income Changes on the Acquisition of Food by Low-Income Households". Washington, D.C.: International Food Policy Research Institute.

Ali, Shaukat (1985). "Household Consumption and Savings Behaviour in Pakistan: An Application of the Extended Linear Expenditure System". Pakistan Development Review. Vol. XXIV, No. 1. pp. 23-38.

Blundell, Richard, and Rajan Ray (1984). "Testing for Linear Engel Curves and Additive Separable Preferences Using a New Flexible Demand System". Economic Journal. Vol. 94. pp. 800-811.

Cornelisse, Peter, and Syed Nawab Haider Naqvi (1984). "The Anatomy of the Wheat Market in Pakistan". Rotterdam: Centre for Development Planning.

Deaton, Angus (1975). "The Measurement of Income and Price Elasticities". European Economic Review. Vol. 6. pp. 261-274.

Deaton, Angus (1986). "Quality, Quantity, and Spatial Variation of Price". Wood row Wilson School, Princeton University. (Discussion Paper No. 127)

Deaton, Angus, and John Muellbauer (1980). "An Almost Ideal Demand System" American Economic Review. Vol. 70. pp. 312-326.

Hausman, Jerry (1978). "Specification Tests in Econometrics". Econometrica. Vol. 46. pp. 251-271.

Mukhtar, Hanid (1985). "Essays in Consumer Behavior: Evidence from Pakistani Data". Unpublished Ph.D. Thesis, Boston University.

Pakistan, Government of (1978). Micronutrient Survey. Islamabad: Planning Division.

Ray, Rajan (1982). "The Testing and Estimation of Complete Demand Systems on Household Budget Surveys: An Application of AIDS". European Economic Review. Vol. 17. pp. 349-369.

Timmer, Peter (1974). "A Model of Rice Marketing Margins in Indonesia". Food Research Institute Studies. Vol. XIII. pp. 145-168. 